\section{Micropropagation of Six Rockrose (Cistus) Species}

\author{
José M. Iriondo, Carmen Moreno, and César Pérez \\ Departamento de Biología Vegetal, Escuela Tecnica Superior de Ingenieros \\ Agronomos, Universidad Politécnica de Madrid, 28040 Madrid, Spain
}

Additional index words. plant tissue culture

\begin{abstract}
Micropropagation methods for six rockrose species (Cistus albidus L., C. clusii Dunal, C. ladanifer L., C. laurifolius L., C. psilosepalus L., and C. salvifolius L.) were established. Cultures, initiated from nodal segments of seedlings, were grown on MS medium, alone, or supplemented with $0.88 \mu_{\mathrm{M}}$ BAP or $0.93 \mu_{\mathrm{M}}$ Kin. Multiple shoot formation was obtained after the first subculture ( 30 days) from which new nodal segments were taken and grown on the same culture medium to maintain proliferation. Shoots obtained at the third subculture were rooted alone or supplemented with different concentrations of IBA. The plantlets of the six species, thereby obtained, were successfully acclimatized to ex vitro conditions. Chemical names used: 6-benzylaminopurine (BAP), indole-3-butyric acid (IBA), 6-furfurylaminopurine (Kin).
\end{abstract}

The Cistaceae family is comprised of eight genera and $\approx 165$ species distributed throughout the temperate regions in the northern hemisphere and South America. It is found in the Mediterranean Basin, where it forms an important part of the shrubs, especially in noncalcareaous soils where it is widely distributed.

Several Cistus spp. are used as ornamentals for their flowers, produced in abundance and notable for their size and singular beauty. In the United States, Cistus spp. have a great potential in the west and southwest due to their drought tolerance. Rockroses are regarded as melliferous flora, the honey obtained from them being of great economic interest. A gum (ladanum) also is obtained from some Cistus spp., especially $C$. ladanifer. Ladanum, traditionally used in medicinal plasters, is used extensively in perfumery (Brickell, 1989; López, 1982; Polunin and Huxley, 1972). A novel use for Cistus spp. involves inoculating them with the mycorrhizae of Tuber nigrum Bull (a black truffle) and planting them in a primary stage of truffle forest repopulation (Pacioni, 1987).

Cistus spp. multiply naturally by seed, although germination is low and erratic due to hard-seededness (Thanos and Georghiou, 1988). The diverse hybrids and cultivars used in gardening are multiplied exclusively by softwood cuttings and layering (Brickell, 1989). However, vegetative propagation is difficult in most wild Cistus species (Siguero, 1991). Micropropagation of six Cistus species gation of wild Cistus germplasm, which may prove useful in initial selection stages of a breeding program. Our objective was to develop a simple micropropagation system ap-

Received for publication 18 Nov. 1994. Accepted for publication 26 Apr. 1995. The cost of publishing this paper was defrayed in part by the payment of page charges. Under postal regulations, this paper therefore must be hereby marked advertisement solely to indicate this fact. was attempted as an alternative for the propa- plicable to a wide range of genotypes in each species. To our knowledge, there are few studies on the micropropagation of Cistaceae (M'Kada et al., 1991; Morte and Honrubia, 1992).

\section{Materials and Methods}

To overcome hard-seededness, mature seeds of C. albidus, C. clusii, C. ladanifer, $C$. laurifolius, $C$. psilosepalus, and $C$. salvifolius were subjected to a dry-heat pretreatment at $100 \mathrm{C}$ for 10 to $30 \mathrm{~min}$, depending on the species (Corral et al., 1989; Thanos and Georghiou, 1988; Trabaud and Oustric, 1988, 1989). Seeds then were surface-sterilized by immersion in a solution of $1.5 \% \mathrm{NaOCl}$ for 30 $\mathrm{min}$, followed by three rinses of $5 \mathrm{~min}$ each with sterile distilled water.

Basal medium consisted of MS medium (Murashige and Skoog, 1962), 3\% sucrose, and $0.7 \%$ Difco Bacto agar. The $\mathrm{pH}$ was adjusted to 5.8 before autoclaving (121C for 20 min). Seeds were sown on MS basal medium without growth regulators. Thirty days after sowing, nodal segments $(0.5$ to $1 \mathrm{~cm})$ were excised from seedlings and placed on three media: MS basal medium, MS $+0.93 \mu \mathrm{M} \mathrm{Kin,}$ or MS $+0.88 \mu \mathrm{M}$ BAP. Every 4 weeks, nodal segments $(0.5$ to $1 \mathrm{~cm})$ were subcultured to the same media. Microshoots from the third subculture were transplanted to MS basal medium or MS supplemented with IBA $(0.49,0.98$, $1.97,2.95,3.94$, and $4.90 \mu \mathrm{M}$ ) for rooting. In all micropropagation steps, $7 \times 8$-cm glass culture vessels, containing $30 \mathrm{ml}$ of culture medium, were used.
Rooted plantlets were washed to remove agar, and roots were sprayed with a 0.3$\mathrm{g} \cdot 1$ iter ${ }^{-1}$ carbendazim solution [0.6 g Bavistin/ liter(BASFEspañola, Barcelona, Spain)]. Then the plantlets were transferred to 0.5 -liter pots containing a 5 sterilized peat : 2 vermiculite mixture (v/v), covered with inverted jars to avoid excessive water loss, and maintained under greenhouse conditions. The plants were irrigated every 2 days with water. Jars were removed 6 weeks after transfer to pots, and 1 week later, the plants were transplanted to soil in the field.

All cultures were grown at $25 \pm 1 \mathrm{C}$ under a 16-h photoperiod with a light intensity of 60 $\mu \mathrm{mol} \cdot \mathrm{m}^{-2} \cdot \mathrm{s}^{-1}$ provided by cool-white fluorescent lamps. At least 20 explants were used for each treatment and each experiment was conducted three times. Analysis of variance and Duncan's multiple range test $(P<0.05)$ were performed on the number of shoots per explant. Polynomial regressions were applied to the percentage of rooted microcuttings and the number of roots per microcutting.

\section{Results and Discussion}

After 30 days in culture, shoot proliferation was evident for all six Cistus species in the three media. Cistus clusii had the lowest proliferation percentages ( $73 \%$ to $82 \%$ ), whereas the values were between $80 \%$ and $97 \%$ for the other five species.

Growth regulator type had a significant effect on the number of shoots per explant after three subcultures, and results varied with the species (Table 1). In C. albidus, $C$. laurifolius, and $C$. salvifolius, the highest number of shoots per explant were obtained when the MS medium was supplemented with 0.88 $\mu \mathrm{M}$ BAP. The response to MS and MS +0.88 $\mu \mathrm{M}$ BAP was similar for C. clusii, C. ladanifer, and $C$. psilosepalus. In all species, except $C$. psilosepalus, the number of shoots per explant in MS $+0.93 \mu \mathrm{M}$ Kin was always significantly lower $(P \leq 0.05)$ than for MS $+0.88 \mu \mathrm{M}$ BAP. This result differed from those of Morte and Honrubia (1992) with nodal segments of seedlings of Helianthemum almeriense Pau, where adding $0.93 \mu \mathrm{M}$ Kin to MS medium produced a significantly higher number of shoots per explant than adding $0.88 \mu \mathrm{M}$ BAP.

In most cases, shoots were significantly shorter with Kin $(0.93 \mu \mathrm{M})$ in the culture medium than with BAP $(0.88 \mu \mathrm{M})$ or without growth regulators (data not shown). There also were no significant differences attributed to the subculture in this study.

Adventitious roots formed in all six species in all the treatments in MS medium without auxins, with the exception of $C$. salvifolius
Table 1. Effects of BAP or Kin on number of shoots per explant in six Cistus species after 4 weeks in culture. ${ }^{2}$

\begin{tabular}{lcccccc}
\hline \hline $\begin{array}{l}\text { Growth } \\
\text { regulator }\end{array}$ & \multicolumn{7}{c}{ No. shoots/explant } \\
\cline { 2 - 7 }$(\mu \mathrm{M})$ & C. albidus & C. clusii & C. ladanifer & C. laurifolius & C. psilosepalus & C. salvifolius \\
\hline Control & $1.8 \mathrm{~b}$ & $2.5 \mathrm{a}$ & $2.8 \mathrm{a}$ & $1.1 \mathrm{~b}$ & $3.0 \mathrm{a}$ & $1.7 \mathrm{c}$ \\
$0.93 \mathrm{Kin}$ & $2.0 \mathrm{~b}$ & $1.6 \mathrm{~b}$ & $2.0 \mathrm{~b}$ & $1.2 \mathrm{~b}$ & $3.1 \mathrm{a}$ & $2.6 \mathrm{~b}$ \\
$0.88 \mathrm{BAP}$ & $2.8 \mathrm{a}$ & $2.3 \mathrm{a}$ & $2.7 \mathrm{a}$ & $2.5 \mathrm{a}$ & $3.2 \mathrm{a}$ & $4.8 \mathrm{a}$ \\
\hline
\end{tabular}

${ }^{2}$ Mean separation in columns by Duncan's multiple range test at $P \leq 0.05$. 
Table 2. Effects of IBA on the percentage of rooted microcuttings and the number of roots per microcutting for six Cistus species after 4 weeks in culture.

\begin{tabular}{|c|c|c|c|c|c|c|c|c|c|c|c|c|}
\hline \multirow{2}{*}{$\begin{array}{l}\text { IBA } \\
\left(\mu_{M}\right)\end{array}$} & \multicolumn{6}{|c|}{$\%$ Rooted microcuttings ${ }^{\mathrm{z}}$} & \multicolumn{6}{|c|}{ No. roots/microcutting ${ }^{z}$} \\
\hline & C. $a l b$ & C. clu & C. lad & C. lau & C. psi & C. sal & C. $a l b$ & C. clu & C. lad & C. lau & C. psi & C. sal \\
\hline 0.00 & 72 & 54 & 75 & 40 & 95 & 2 & 2.8 & 2.5 & 5.2 & 4.1 & 7.4 & $\overline{----}$ \\
\hline 0.49 & 70 & 52 & 84 & 51 & 75 & 32 & 2.7 & 3.5 & 5.5 & 3.9 & 6.5 & 2.7 \\
\hline 0.98 & 80 & 55 & 82 & 74 & 86 & 49 & 2.3 & 2.3 & 5.1 & 3.1 & 7.4 & 4.1 \\
\hline 1.97 & 84 & 46 & 92 & 67 & 82 & 48 & 3.4 & 2.1 & 5.7 & 2.8 & 6.6 & 3.8 \\
\hline 2.95 & 81 & 71 & 88 & 68 & 90 & 41 & 3.6 & 2.7 & 5.1 & 4.1 & 7.2 & 2.5 \\
\hline 3.94 & 67 & 71 & 87 & 67 & 99 & 41 & 3.2 & 2.5 & 5.3 & 5.2 & 8.4 & 2.5 \\
\hline 4.90 & 78 & 77 & 78 & 50 & 90 & 42 & 3.6 & 2.3 & 4.7 & 3.1 & 8.3 & 4.4 \\
\hline \multicolumn{13}{|l|}{ Regression } \\
\hline Linear & NS & ** & NS & NS & * & $*$ & $* * *$ & NS & NS & NS & $* *$ & NS \\
\hline Quadratic & NS & $* *$ & * & NS & * & ** & $* * *$ & NS & NS & NS & $* * *$ & NS \\
\hline
\end{tabular}

${ }^{2}$ C. alb $=$ C. albidus; $C$. clu $=$ C. clusii; C. lad $=$ C. ladanifer; C. lau $=$ C. laurifolius; $C$. psi $=$ C. psilosepalus; C. sal $=$ C. salvifolius.

Ns, ***,**** Nonsignificant or significant at $P \leq 0.05,0.01$, or 0.001 , respectively.

(Table 2). Percentage of rooted microcuttings was significantly affected by IBA treatments in C. clusii, C. ladanifer, C. psilosepalus, and C. salvifolius, whereas the number of roots per explant was affected significantly only by IBA treatments in $C$. albidus and $C$. psilosepalus. Thus, the response to the range of IBA concentrations studied was particular for each species. Genotype also seemed to influence the overall rooting capacity. Cistus salvifolius was more difficult to root, whereas C. psilosepalus and C. ladanifer showed high rooting capacity.

In $H$. almeriense, it was necessary to select shoots longer than $15 \mathrm{~mm}$ for rooting to avoid necrosis and death (Morte and Honrubia, 1992). Shoots also increased considerably in length in the rooting media. In our case, this effect was absent in all six species studied.

Survival after acclimatization was assessed 10 weeks after the transfer of plantlets to ex vitro conditions. The highest survival rates were obtained with $C$. psilosepalus $(77 \%)$, followed by C.salvifolius (65\%), C. ladanifer (62\%), C. albidus (57\%), and C. clusii (44\%), the lowest by $C$. laurifolius $(36 \%)$.

A simple procedure has been developed for micropropagation in six rockrose species of economic interest for use in the initial selection stages of a breeding program. All species responded to MS medium containing $0.88 \mu \mathrm{M}$ BAP for multiple shoot production. Easy-toroot species (C. albidus, C. ladanifer, and $C$. psilosepalus) rooted well on a medium without IBA. Cistus clusii, C. laurifolius, and $C$. salvifolius rooted best with IBA $(0.49$ to 4.9 $\mu \mathrm{M})$ included in the medium. IBA at $4.9 \mu \mathrm{M}$ was an effective treatment for all species. Additional research is warranted to develop micropropagation methods starting from mature explants, which would be useful for the propagation of advanced cultivars obtained from this germplasm.

\section{Literature Cited}

Brickell, C. 1989. Gardeners' encyclopedia of plants and flowers. Dorling Kindersley, London.

Corral, R., J.M. Pita, and F. Pérez-García. 1989. Some aspects of seed germination in four species of Cistus L. Seed Sci. \& Technol. 18:321325.

López, G. 1982. La Guía de Incafo de los arboles y arbustos de la Península Ibérica. Incafo, Madrid, Spain.
M'Kada, J., N. Dorion, and C. Bigot. 1991. In vitro propagation of Cistus xpurpureus Lam. Scientia Hort. 46:155-160.

Morte, M.A. and M. Honrubia. 1992. In vitro propagation of Helianthemum almeriense Pau (Cistaceae). Agronomie 12:807-809.

Murashige, T. and F. Skoog. 1962. A revised medium for rapid growth and bioassays with tobacco tissue cultures. Physiol. Plant. 15:473497.

Pacioni, G. 1987. El cultivo moderno y rentable de la trufa. De Vecchi, Barcelona, Spain.

Polunin, O. and A. Huxley. 1972. Flowers of the Mediterranean. Chatto and Windus, London.

Siguero, P.L. 1991. Consejos y recomendaciones para reforestar con especies autóctonas. Quercus 62:52-53.

Thanos, C.A. and K. Georghiou. 1988. Ecophysiology of fire-stimulated seed germination in Cistus incanus ssp. creticus (L.) Heywood and $C$. salvifolius L. Plant Cell Environ. 11:841-849.

Trabaud, L. and J. Oustric. 1988. Heat requirements for seed germination of three Cistus species in the garrigue of southern France. Flora 183:321325.

Trabaud, L. and J. Oustric. 1989. Influence du feu sur la germination des semences de quatre spèces ligneuses méditerranéennes à reproduction sexuèe obligatoire. Seed Sci. \& Technol. 17:589599. 